\title{
Developing A Storybook as Supplementary Material for Junior High Schools Students Based on Kalimantan Legends
}

\author{
Ribud Rinardi \\ Universitas Tanjungpura \\ ribudrinardi2014@gmail.com \\ Ikhsanudin \\ Universitas Tanjungpura \\ ikhsanudin@fkip.untan.ac.id \\ Regina \\ Universitas Tanjungpura \\ regina@fkip.untan.ac.id
}

\begin{abstract}
The main purpose of this research is to develop a storybook for junior high school students based on Kalimantan Legends. The participant of this research were 60 students of junior high school, and an educational expert from Kabupaten Sambas. This research used the platform of design and development research proposed by Richey and Klein. The procedure used is the framework of Jolly and Bolitho, that consist of need analysis, material grid, first draft, evaluation, and final draft. The data of this research has been collected through questionnaires. There were five questionnaires employed in this research. The first questionnaire was given to the students to investigate the need of the students on reading materials based on Kalimantan Legends. The second questionnaire was employed to know the favorite legends of students. From the need analysis result, it can be concluded that students are interested in reading $(68.30 \%)$, they like to read stories $(90 \%)$. The students are interested to read their local stories $(95 \%)$, and they like the stories with adequate illustrations to help them understand the stories completely $(70 \%)$. On the other hand, they thought that the stories they have in their textbooks were not interesting $(65 \%)$.
\end{abstract}

Keywords: Legends, Material Development, Reading, Storybook

\section{INTRODUCTION}

Reading is an important skill for students to master. Through a good reading ability, students can read their textbook by themselves without many help from teachers. Graesser in McNamara claims that reading is an extraordinary achievement when we consider how many stages and components that must be mastered to achieve comprehension (McNamara, 2007). That is why, a good reading ability supports students to do their assignment and examination better than the students who do not have that ability. Unfortunately, this is not an easy thing to make EFL students to master reading skill (Alqarni, 2015). This might happen since reading covers many things to cover to achieve comprehension. 
In fact, the condition in the real classrooms in junior high schools are far from ideal. Due to the lack of learning sources, the teachers usually rely merely on the workbooks provided by the school to teach their students the reading skills. The quality of those workbooks are doubtful, though. The appropriateness of the texts to the students is one of the issues faced by the teachers when they use their workbooks in the classrooms. The text sometimes unfimiliar for the students. Some texts even seem too strange for them. Moreover, the students of junior high schools had the difficulties in comprehending the text especially in narrative text. It can be seen from their unsatiafactory achievement in the previous sumative test. Shen and Huang claim that low-esteem in reading has long become a big problem among EFL students (Shen \& Huang, 2007). On the other hand, Rafferty and Bernard in 2012 argue that the difficulties faced in reading comprehension by learners especially EFL learners is usually caused by the gap of the learner's first language and the target language (Rafferty \& Bernard, 2012). That is why we need a suitable reading materials for them to promote comprehension.

In fact, the condition in the real classrooms in junior high schools are far from ideal. Due to the lack of learning sources, the teachers usually rely merely on the workbooks provided by the school to teach their students the reading skills. The quality of those workbooks are doubtful, though. The appropriateness of the texts to the students is one of the issues faced by the teachers when they use their workbooks in the classrooms. The text sometimes unfimiliar for the students. Some texts even seem too strange for them. That is the reason why the students hard to comprehend the texts. Furthermore, the workbooks used are not interesting, since they are printed in black and white version. This condition make the reading situation getting worse in the classroom.

Furthermore, in line with the conditions preceded previously, in everyday teaching acticitiy, the teachers must face the fact that the workbooks they use are not enough for achiving the aim for reading purposes. That is why, teachers need supplementary materials. The supplementary materials hopefully can develop students' reading ability appropriately based on their level and interesting for them. This became important since the main thing in reading is focus on how to motivate the reader to read the provided text (Duffy, 2009.p.3).

Through this research, the researcher tried to develop the appropriate reading materials for the students as the supplementary materials. The material should be appropriate for the students too. Jacobs argues that the appropriate reading materials are important to build the readers' motivation to read more (Jacobs, 1997). The materials was presented in the style of story book, to make them interested to read the story. A storybook is chosen since storybook reading has been correlated to a variety of reading factors, including children's eagerness to read (Allor \& McCathren, 2003 cited in Lange \& Thompson, 2006).

Many researchers in Tanjungpura University were done their research in the scope of local contents. Zulkarnaen and Novinty (2016) found that the textbook used in junior high schools werep lack of local contents, especially in the case of stories. On the other hand, Puspita (2016) focused on the usage of supplementary materials in the classroom were crucial to make sure that materials the students get were well-prescribed.

\section{METHOD}

\section{Conceptual framework of the study}

This research used the design and development method. Design and development is a method that focusing on developing a certain product (Sugiyono, 2013.p. 407). This research is conducted to produce a suitable reading materials for students of junior high schools where they have the problem on reading materials availability.

Design, development and evaluation are the holistic process to develop the materials that the writer will use. Furthermore, according to Richey and Klein (2007, p. 8), in design and 
development research, this research will accomplish these goals through two large categories of research projects: the product with tool and model research.

\section{Participants of Research}

\section{Educational expert}

An expert in education bureau in Sambas Regency was invited as the expert in this research. The expert must also know the characteristics of students in Sambas. The expert must have adequate ability in English, so that he can understand well the developed materials.

\section{Local People}

In this research, two local people were chosen to validate the contents. The validity of the legends in the storybook as the product of this research compared to the versions of the legends the local society have in their community.

\section{Teacher}

In this research, a teacher who teach religion in the school was chosen to validate the moral values mentioned in the last part of each legends. This validation was administered to find out the agreement of the moral values in the storybook to the religious and social values in readers' life.

\section{Students}

The sample of this study is the students of junior high schools. There were 60 students of junior high school that involved in the need analysis of this study. They consist of 20 students of grade VII, 20 students of grade VIII, and 20 students represent grade IX.

\section{Research Instruments}

The instruments of data collecting in this research were questionnaires. The qustionnaires cover students' needs, students' favorite legends, expert's jugement, contents' valiity, and moral values validity.

\section{Students' Needs}

The first questionnaire was adaptated from Hutchison and Waters that covered necessity, preference, length, contents, and follow up (Hutchison \& Waters, 1991. p. 55-59). The organization of the first questionnaire can be seen in the following table.

Table 1. The Organization of The Need Analysis Questionnaire

\begin{tabular}{llcl}
\hline No & \multicolumn{1}{c}{ Aspect } & $\begin{array}{c}\text { Number } \\
\text { of Item }\end{array}$ & \multicolumn{1}{c}{ Purpose of Questions } \\
\hline & Students personal identity & \multicolumn{2}{c}{$\begin{array}{l}\text { To find out personal information about } \\
\text { the students }\end{array}$} \\
\hline 1 & Necessity & 1,2 & $\begin{array}{l}\text { To find out the students' opinion towards } \\
\text { reading. }\end{array}$ \\
\hline 2 & Preference & $3,4,5,6$ & $\begin{array}{l}\text { To find out the students' preferance to be } \\
\text { included in the storybook. }\end{array}$ \\
\hline 3 & Length & 7 & $\begin{array}{l}\text { To find out the students' favoured length } \\
\text { of story. }\end{array}$ \\
\hline 4 & Contents & 8,9 & $\begin{array}{l}\text { To find out the moral values and } \\
\text { illustration usage for students. }\end{array}$ \\
\hline 5 & Follow Up & 10 & $\begin{array}{l}\text { To find out the activities the students } \\
\text { favour after reading. }\end{array}$ \\
\hline
\end{tabular}




\section{Students' Favorite Kalimantan Legends}

The second one is the questionnaire to find out the students' favorite legends to be included in the storybook. The organization of the second questionnaire can be drawn in the table below.

Table 2. Students' Favorite Legends

\begin{tabular}{|c|c|c|}
\hline No & Title & Origin \\
\hline 1 & The Legend of Batu Menangis & Kalimantan \\
\hline 2 & The Legend of Batu Ballah Batu Betangkup & Sambas \\
\hline 3 & The Legend of Bujang Nadi and Dare Nandung & Sambas \\
\hline 4 & The Legend of Batu Betarup (Novianti \& Suwando, 2015) & Sambas \\
\hline 5 & The Legend of Batu Dara Muning (Morario, 1996) & Sintang \\
\hline 6 & The Legend of Bujang Beji (Heriana, 2005) & Sintang \\
\hline 7 & The Legend of Putri Daranante (Heriana, 2005) & Sanggau \\
\hline 8 & The Legend of Sungai Landak & Landak \\
\hline 9 & The Legend of Baba Cingak & Sanggau \\
\hline 10 & The Legend of Kote Pak Aloi (Sahara, 2003) & Sambas \\
\hline 11 & The Legend of Dato' Kullup & Sambas \\
\hline 12 & The Legend of Batu Bejamban & Sambas \\
\hline 13 & The Legend of Semangka Emas (Heriana, 2005) & Sambas \\
\hline 14 & The Legend of Burung Ruai & Sambas \\
\hline 15 & The Legend of Bukit Kujau & Sintang \\
\hline 16 & The Legend of Putri Junjung Buih & Ketapang \\
\hline 17 & The Legend of Konyat (Rinja, 2001) & Ketapang \\
\hline 18 & The Legend of Belanga and the Princess (Heriana, 2005) & Kapuas Hulu \\
\hline 19 & The Legend of Gunung Senujuh (Novianti \& Suwando, 2015) & Sambas \\
\hline 20 & The Legend of Lawang Kuari (Novianti \& Suwando, 2015) & Sekadau \\
\hline 21 & Junjat Janju (Heriana, 2005) & Bengkayang \\
\hline 22 & The Legend of Danau Sebedang (Novianti \& Suwando, 2015) & Sambas \\
\hline
\end{tabular}

\section{Procedures}

This research used David Jolly and Rod Bolitho's framework (see Figure 1). The writer have applied this framework in developing a storybook based on Kalimantan Legends. Jolly and Bolitho state, "Most materials writers move in this direction, and use some or all of these steps, 
if not always precisely in this order" (Tomlinson, 2011). In order to simplify and deal with the real situation, and the undynamic state of the whole steps of this framework, the researcher needed simpler steps to develop or design the materials. That is why, the writer used the modified version of this framework.

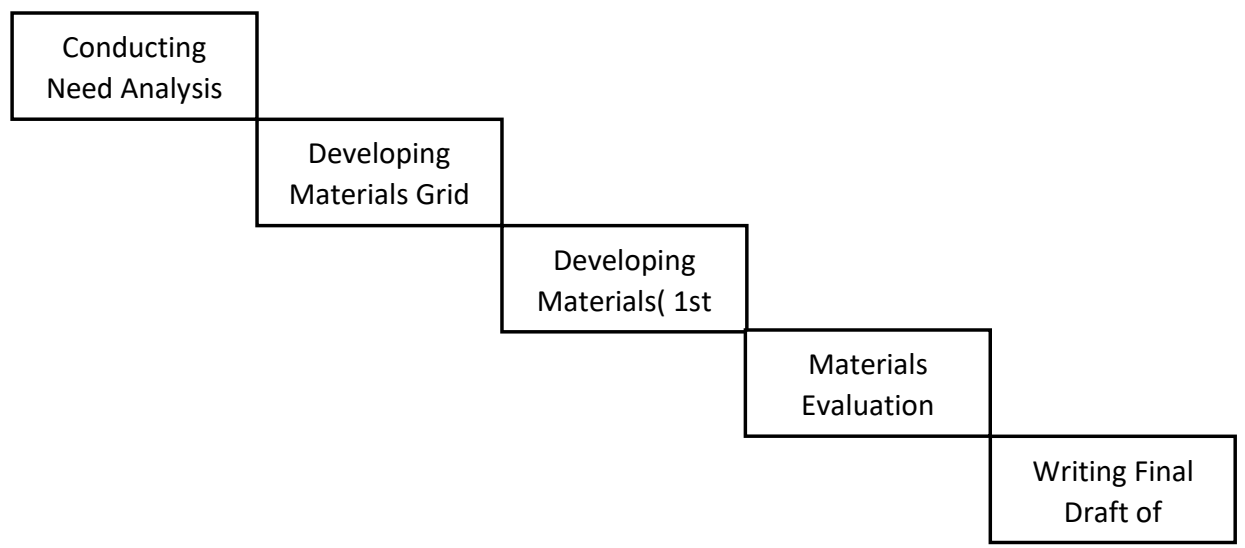

Fig 1. Procedures in Developing Materials Based on Jolly and Bolitho Framework

\section{RESULTS AND DISCUSSIONS}

\section{Results}

a) Necessities

The necessities part is related to hot important the reading activity is for the students. In this study, the results of students' necessities can be drawn as follow.

Table 3. Necessities

\begin{tabular}{|c|c|c|c|c|}
\hline No & Question & $\mathrm{N}$ & $\begin{array}{l}\text { Respondents' } \\
\text { Answer }\end{array}$ & Percentage \\
\hline 1 & Based on your opinion, reading is.... & 60 & & \\
\hline & A. Very important & & 17 & 28.3 \\
\hline & B. Important & & 24 & 40 \\
\hline & C. Neutral & & 12 & 20 \\
\hline & D. Less important & & 2 & 3.33 \\
\hline & E. Not important & & 5 & 8.33 \\
\hline 2 & Do you like reading a story? & 60 & & \\
\hline & A. Love it & & 21 & 35 \\
\hline & B. Like it & & 33 & 55 \\
\hline & C. Neutral & & 0 & 0 \\
\hline & D. Less interested & & 5 & 8.33 \\
\hline & E. Hate it & & 1 & 1.67 \\
\hline
\end{tabular}

This table intended know the opinion of the student about reading based on their personal opinion and students interest on reading stories. From table 6 point 1, 40\% of the students agreed that reading is important for them. On the other hand, $28.30 \%$ students think that reading is very 
important for them. From the table above, it can be concluded that the majority of the students $(68.30 \%)$ agreed that reading is important for them. In table 3 point 2, the intention is to know whether the students like reading or not. From the table 4.1 point 2 above, it can be concluded that $55 \%$ of the students thought that they like reading a story. The positive respons from the students towards this question is $90 \%$.

b) Preference

Preference refers to what the students want in their reading materials. The freference focused on the reading materials they wanted to have in their daily life. In this study, the data about preference are presented as follows.

Table 4. Preferences

\begin{tabular}{|c|c|c|c|c|}
\hline No & Question & $\mathrm{N}$ & $\begin{array}{l}\text { Respondents' } \\
\text { Answer }\end{array}$ & Percentage \\
\hline 3 & $\begin{array}{l}\text { Do you like to read the stories that } \\
\text { you have in your textbooks? }\end{array}$ & 60 & & \\
\hline & A. Love it & & 11 & 18.33 \\
\hline & B. Like it & & 20 & 33.33 \\
\hline & C. Neutral & & 3 & 5.00 \\
\hline & D. Less interested & & 17 & 28.33 \\
\hline & E. Hate it & & 9 & 15.00 \\
\hline 4 & $\begin{array}{l}\text { Are you interested with the stories } \\
\text { that you have in your textbooks? }\end{array}$ & 60 & & \\
\hline & A. Very interested & & 13 & 21.67 \\
\hline & B. Interested & & 8 & 13.33 \\
\hline & C. Neutral & & 22 & 36.67 \\
\hline & D. Less interested & & 14 & 23.33 \\
\hline & E. Not interested & & 3 & 5.00 \\
\hline 5 & $\begin{array}{l}\text { Are you interested if your local } \\
\text { stories become your English } \\
\text { reading materials? }\end{array}$ & 60 & & \\
\hline & A. Very interested & & 14 & 23.33 \\
\hline & B. Interested & & 43 & 71.67 \\
\hline & C. Neutral & & 2 & 3.33 \\
\hline & D. Less interested & & 0 & 0.00 \\
\hline & E. Not interested & & 1 & 1.67 \\
\hline 6 & $\begin{array}{l}\text { Are you interested to read stories } \\
\text { with pictures? }\end{array}$ & 60 & & \\
\hline & A. Very interested & & 35 & 58.33 \\
\hline & B. Interested & & 7 & 11.67 \\
\hline & C. Neutral & & 9 & 15.00 \\
\hline & D. Less interested & & 6 & 10.00 \\
\hline & E. Not interested & & 3 & 5.00 \\
\hline
\end{tabular}


c) Length

In this part, the questions wanted to find out the length of the texts that the students wanted to read, and also about the usage of moral values of stories to students daily life. The length data can be presented as follow.

Table 5. Length

\begin{tabular}{|c|c|c|c|c|}
\hline No & Question & $\mathrm{N}$ & $\begin{array}{l}\text { Respondents' } \\
\text { Answer }\end{array}$ & Percentage \\
\hline \multirow[t]{6}{*}{7} & $\begin{array}{l}\text { How long a story should be that you } \\
\text { want to read? }\end{array}$ & 60 & & \\
\hline & A. 1-2 paragraphs & & 22 & 36.67 \\
\hline & B. 2-3 paragraphs & & 8 & 13.33 \\
\hline & C. 3-4 paragraphs & & 23 & 38.33 \\
\hline & D. 4-5 paragraphs & & 6 & 10.00 \\
\hline & E. 5-6 paragraphs & & 1 & 1.67 \\
\hline
\end{tabular}

Table 5 consist of 1 item that focused on the length of the text the participants wanted to read. From table 5, it shows that most of the students wanted a short text to be in their reading materials. Most of students (38.33) thought that the length of the texts they wanted to read is from 3 to 4 paragraphs.

\section{c) Contents}

The focus of content part is to find out the desired things should be invloved in the reading text according to the participants' opinion. This part consisted of 2 items. The data of contents part can be seen in table 9 below

Table 6. Contents

\begin{tabular}{llccc}
\hline No & \multicolumn{1}{c}{ Question } & N & $\begin{array}{c}\text { Respondents' } \\
\text { Answer }\end{array}$ & Percentage \\
\hline 8 & $\begin{array}{l}\text { How important do the moral values } \\
\text { of the stories to your daily life? }\end{array}$ & 60 & & \\
\hline & A. Very important & 0 & 0.00 \\
\hline B. Important & 34 & 56.67 \\
\hline C.Neutral & 25 & 41.67 \\
\hline D. Less important & 0 & 0.00 \\
\hline E. Not important & 1 & 1.67 \\
\hline 9 & $\begin{array}{l}\text { Do the pictures in the stories helpful } \\
\text { to make you understand the stories? }\end{array}$ & 60 & & 61.67 \\
\hline & A. Very helpful & 37 & \\
\hline
\end{tabular}




\begin{tabular}{lcc}
\hline B. Helpful & 14 & 23.33 \\
\hline C. Neutral & 6 & 10.00 \\
\hline D. Less helpful & 3 & 5.00 \\
\hline E. Not helpful & 0 & 0.00 \\
\hline
\end{tabular}

From table 6 above, the result of contents part can be described as follow. From point 1 in table 6 focused on the importance of moral values of the stories to participants' daily life. The participants mostly though that moral values they got from the stories they read tend to be important for their life. It represented by $56.67 \%$ of respondents or 34 of 60 students thought that the moral values from stories they read were important for them.

Furthermore, in table 6 point 2 , focused on whether the pictures or illustrations in the reading materials help them tu understand the stories. Surprisingly, $85 \%$ of participants or 52 of 60 students thought that they would understand easier stories if they are accompanied by pictures as illustrations.

d) Follow Up

This part of the questionnaire wanted to find out the activities after reading the text that the students favoured. The result of follow up section can be drawn as follow.

Table 7. Follow Up

\begin{tabular}{|c|c|c|c|c|}
\hline No & Question & $\mathrm{N}$ & $\begin{array}{l}\text { Respondents' } \\
\text { Answer }\end{array}$ & Percentage \\
\hline \multirow[t]{6}{*}{10} & $\begin{array}{l}\text { Based on your opinion, after you } \\
\text { read a story, what is the form of the } \\
\text { task you favoured to do? }\end{array}$ & 60 & & \\
\hline & A. Essay questions & & 3 & 5.00 \\
\hline & B. Retell the stories & & 1 & 1.67 \\
\hline & C. Multiple choice questions & & 15 & 25.00 \\
\hline & D. Matching task & & 17 & 28.33 \\
\hline & E. True and false questions & & 24 & 40.00 \\
\hline
\end{tabular}

From table 7 above, the majority of the students thought that true-false questions would be the best activities after their reading $(40.00 \%)$.

\section{Students Favorite Legends}

This part of the questionnaire shows the result of students' choice on legends title that they chose. The result of this questionnaire had been taken as the title included in the developed storybook. 
International Journal of Learning and Instruction

Volume 1 I Number 1 I April 2019

Table 8. Students' Favorite Legends

\begin{tabular}{clccc}
\hline No & \multicolumn{1}{c}{ Title } & $\mathbf{N}$ & $\mathbf{R}$ & Percentage \\
\hline 1 & The Legend of Batu Betarup & 60 & 9 & 15,00 \\
\hline 2 & The Legend of Batu Menangis & 60 & 8 & 13,33 \\
\hline 3 & The Legend of Bujang Nadi and Dare Nandung & 60 & 8 & 13,33 \\
\hline 4 & The Legend of Semangka Emas & 60 & 8 & 13,33 \\
\hline 5 & The Legend of Batu Ballah Batu Betangkup & 60 & 7 & 11,67 \\
\hline 6 & The Legend of Batu Dara Muning & 60 & 6 & 10,00 \\
\hline 7 & The Legend of Burung Ruai & 60 & 3 & 5,00 \\
\hline 8 & The Legend of Kote Pak Aloi & 60 & 2 & 3,33 \\
\hline 9 & The Legend of Dato' Kullup & 60 & 2 & 3,33 \\
\hline 10 & The Legend of Danau Sebedang & 60 & 2 & 3,33 \\
\hline 11 & The Legend of Bujang Beji & 60 & 1 & 1,67 \\
\hline 12 & The Legend of Putri Daranante & 60 & 1 & 1,67 \\
\hline 13 & The Legend of Batu Bejamban & 60 & 1 & 1,67 \\
\hline 14 & The Legend of Putri Junjung Buih & 60 & 1 & 1,67 \\
\hline 15 & The Legend of Belanga and the Princess & 60 & 1 & 1,67 \\
\hline & & & & \\
\hline
\end{tabular}

Table 8 above is focused on the favorite legends the participants wanted to be in the reading materials. The legends were come from many places in West Kalimantan. From the table above, it can be concluded that the title that the participants favoured mostly the legends from Sambas. It is because of the participants taken in this research were the students of junior high schools from Sambas Regency. That is why, the majority of the legends' title that included in the story book as the product of this research were the legends that originated from Sambas Regency (4 of 6 legends).

\section{Discussion}

This research aimed to develop a storybook as supplementary materials for junior high school students based on Kalimantan Legends. Developing a storybook as a supplementary material seems to be important since there were very limited storybooks that provide the stories in English. That is why, it is hard for students to find the material for their reading. That is why, this research proposed as the solution in overcoming this problem.

The storybook developed in this study is in line with the syllabus Kurikulum 2013 for Junior High Schools. In accordance to the curriculum, the narrative genre of text is involved into junior high school syllabus, in which the legend is a part of narrative texts. Before the storybook were developed, the researcher should do the need analysis. The need analysis was administered to find out the need of the readers on the reading materials based on Kalimantan legends.

The need analysis was aministered to 60 students of junior high school in Sambas Regency from grade 7, 8, and 9. The result of need analysis can be drawn as follow. The students of junior high schools are interested in reading. That is why, the majority of the students answered positively through this question $(68.30 \%)$. Furthernore, the students also like to read stories. It can be shown 
that almost all of the students answered positively towards this question (90\%). On the other hand, the students are interested to read their local stories $(95 \%)$. That is the reason why the stories that included in the storybook were derived from their local stories. The students also like the stories with adequate illustrations to help them understand the stories completely $(70 \%)$. That is why, the developed storybook contains many illustrations to boost students understanding towards the stories. On the other hand, they thought that the stories they have in their textbooks were not interesting (65 $\%)$.

Since the main focus of this study is to develop a storybook based on Kalimantan legends, the themes of the materials in the storybook is also connected to Kalimantan legends. This can be seen from the title of each units that took the title of the legends as the unit themes. The storybook developed was in line with the result of the need analysis that showed the most students wanted to have legend stories to be their reading materials.

The developed storybook consist of 6 units such as : 1) Unit 1: The Legend of Batu Menangis; 2) Unit 2: The Legend of Batu Ballah Batu Betangkup; 3) Unit 3: The Legend of Bujang Nadi and Dare Nandung; 4) Unit 4: The Legend of Batu Betarup; 5) Unit 5: The Legend of Semangka Emas; and 6) Unit 6: The Legend of Batu Dara Muning. These titles of legends were chosen through the students' choice that collected through a questionnaire in collecting students favorite legends. In the questionnaire, the students were given 22 titles of legends from Kalimantan and they had to choose once per student. From the result, the title for unit 1 is The Legend of Batu Menangis (13.33\%), unit 2 is The Legend of Batu Ballah Batu Betangkup (11.67\%), unit 3 is The Legend of Batu Betarup (15\%), unit 4 is The Legend of Bujang Nadi and Dare Nandung (13.33\%), unit 5 is The Legend of Semangka Emas (13.33\%), and unit 6 is The Legend of Batu Dara Muning (10\%).

From the result of the second questionnaire where the students asked about their favorite legends, the majority of the students chose their favorite legends based on how familiar the legends were to them. That is why, the result of the questionnaire shows that the majority of the legends chosen by the students were the legends from Sambas Regency, where the legends were usually told by elders to them.

The organization of the text in the storybook was also in line with grading concept, where simpler texts come first. That is why, the text in 1 is less complicated than the text in unit 6 . The researcher believed that reading a shorter and simpler story at the beginning can promote readers spirit to read the next stories in the upcoming units.

Then, each unit consist of introduction, reading text, vocabulary review, and moral values corner. Every unit in the storybook has the same genre of text, and also has the same material design as previously presented in this study. Introduction parts of the storybook consist of a picture to represent the whole story in the unit, an information box that provide the information about the origin of the legends; let's read section where the main reading text is written. Reading texts including many pictures as the means to help the readers understand the story easily. Vocabulary reviews are the list of 10 words to remember by the readers. This part of the storybook leads the reader to remember the new words used in the texts. The moral value section is the place where the messages from the stories were elicited and listed. This is to simplify the readers to learn for their life in real society.

\section{CONCLUSION AND SUGGESTION Conclusion}

According to the result of needs analysis questionnaire that distributed previously, it can be concluded that the needs of junior high students on reading materials based on Kalimantan Legends can be listed as follows: (1) the students like to read stories; (2) the majority of the students that they did not totally interested to the stories presented in their existing textbooks; (3) the majority of the students thought that the local stories as their reading materials would be interesting; (4) most of students were interested to read stories with pictures and illustrations; and (5) the students thought that moral values they got from stories were important to them in their daily life. 


\section{Suggestion}

The final product of this research is a storybook for junior high school students based on Kalimantan Legends. The result of this research is expected to be beneficial for the following stakeholders, such as: (1) English teacher, the teacher is the one who knows well about their students' needs and background. It is suggested that the English teacher develop his/her own materials for the students based on the need analysis that they conducted. The process of needs analysis can be through classroom observation during his/her teaching and learning process, in order to investigate their needs, lacks, and wants through the developed materials; and for (2) other researchers are suggested to do a research in the same topics. They should: (1) pay attention to the most important key in developing materials that is the needs analysis; (2) consider to the students' background knowledge and recent ability; (3) the appropriate illustrations should be made to help the students to underrstand the story, since a good illustration will help the students to motivate themselves to read the story.

\section{REFERENCES}

Alqarni, Fawaz. (2015). Collaborative Strategic Reading to Enhance Learners Reading Comprehnsion in English as A Foreign Language.Academic Journal of Interdiciplinary Studies.

Duffy, Gerard. G. (2009). Explaining Reading: A Source for Teaching, Concepts, Skills, and Strategies.New York: The Guilford Press.

Heriana, S. S. (2005). Dayang Putih. Pontianak: Romeo Grafika.

----- (2005). Bujang Beji. Pontianak: Romeo Grafika.

---- (2005). Junjat Janju. Pontianak: Romeo Grafika.

Jacobs, G. M. et. al. (1997). Successful Strategies for Extensive Reading. Singapore: Seameo.

Lange, S.M. \& Thompson, B. (2006). Early Identification and Intervention for Children at Risk for Learning Disability. Journal of Special Education. pp 104.

McNamara, Danielle S. (2007). Reading Comprehension Strategies - Theories, Interventions, and Technologies. New Jersey: Lawrence Erlbaum Associates, Inc., Publishers.

Morario. (1996). Keluarga Pak Aloi dan Dara Muning. Pontianak: Balai Kajian Sejarah dan Nilai Tradisional.

Novianti, E. \& Suwando. (2015). Lawang Kuari: Antologi Cerita Rakyat Kalimantan Barat. Pontianak: Balai Bahasa Provinsi Kalimantan Barat.

Rafferty, E., \& Bernard, E. (2012). Improving Reading Proviciency via Interactive Online. Electronic Journal of Foreign Language Teaching, pp 368.

Richey, Rita C. \& Klein, D. James. (2007). Design and Development Research.New Jersey: Lawrence Erlbaum Associates, Inc.

Rinja,S.(2001). Konyat The Smart Hero. Pontianak: Romeo Grafika.

Shen, M.-Y., \& Huang, Y.-K. (2007). Collaborative Action Research for Reading Strategy Instruction: A Case in Taiwan. Electronic Journal for Foreign Language Teaching, pp 108.

Sugiyono. (2013). Metode Penelitian Pendidikan Pendekatan Kualitatif, Kuantitatif, dan R\&D. Bandung: Alfabeta

Tomlinson, B. (2011). Materials Develop-ment in Language Teaching. Cambridge: Cambridge University Press. 